\title{
JANUARY INITIATION OF SUBURBAN GREAT HORNED OWL NESTS IN MANITOBA
}

CHRISTIAN ARTUSO, Department of Environment and Geography, University of Manitoba, Winnipeg, MB R2T 2N2. E-mail: chartuso@gmail.com

In 2006, two Great Horned Owl pairs began nesting in suburban areas of Winnipeg, Manitoba in mid-January, approximately five to six weeks earlier than any previously recorded breeding date in that province. ${ }^{5}$ Comparison with rural Great Horned Owl nests nearby suggests that the urban heat island phenomenon, in combination with above average January temperatures, may have triggered these extremely early nesting efforts.

The first of these two nests was on the edge of Wildwood Golf Course, a suburban golf course near the Red River (Figures 1 and 2). Two chicks fledged. The older left the nest on the evening of March 30 and flew from the nest tree on March 31 (Figures 3, and 4 $\& 5$ on the inside front cover). The younger chick left the nest on April 2 but remained in the nest tree until April 8. Based on the average incubation period of 33 days and the average period in nest of 42 days, ${ }^{7}$ I estimate the date of clutch initiation to be January 15. The adult male apparently died shortly before the young fledged ( $D$. Swayze, pers. comm.).

The second nest was located on Harris Boulevard, a suburban street along the edge of a golf course near the Assiniboine River. This is the only pair discussed in this article that nested

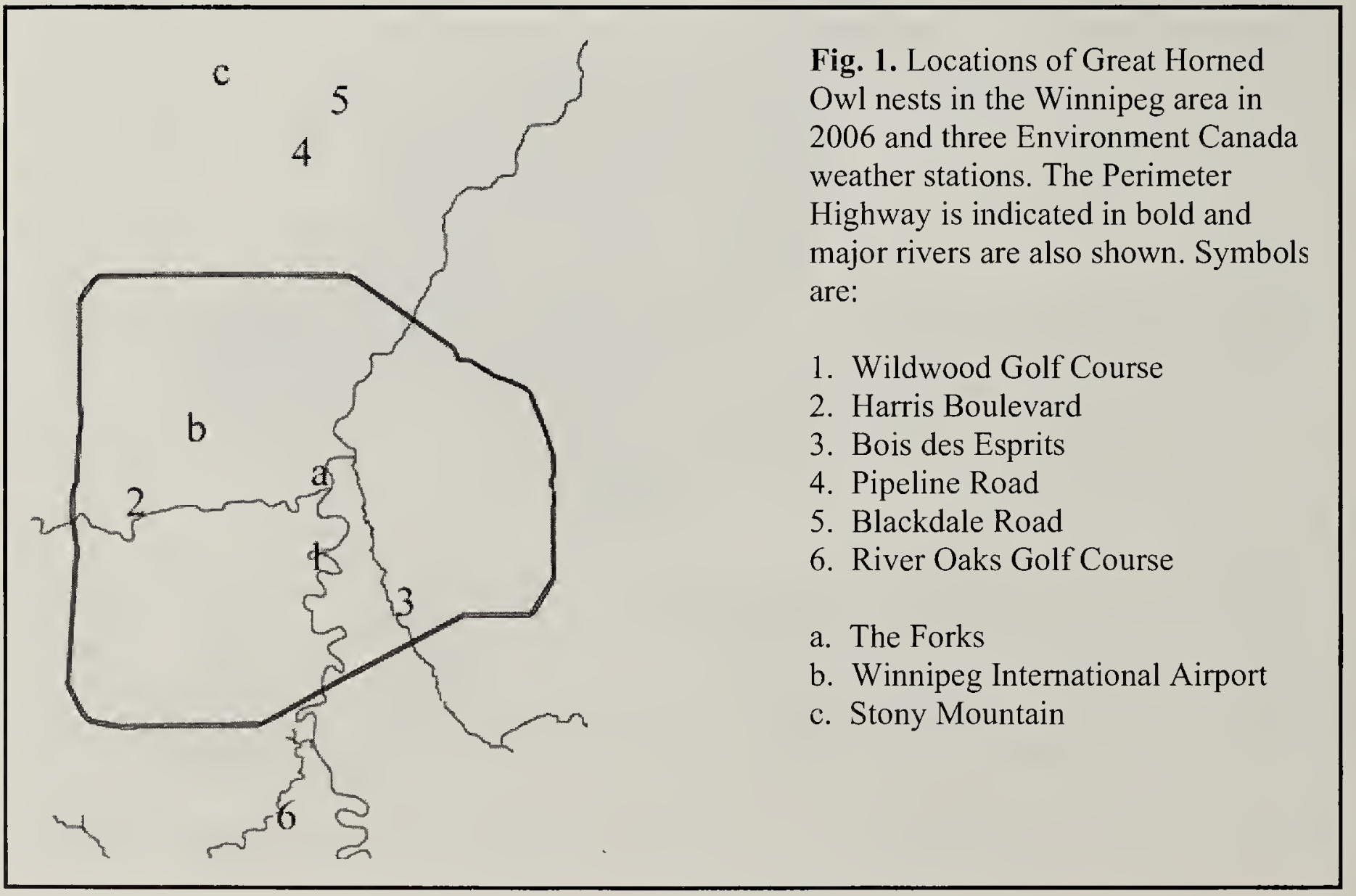




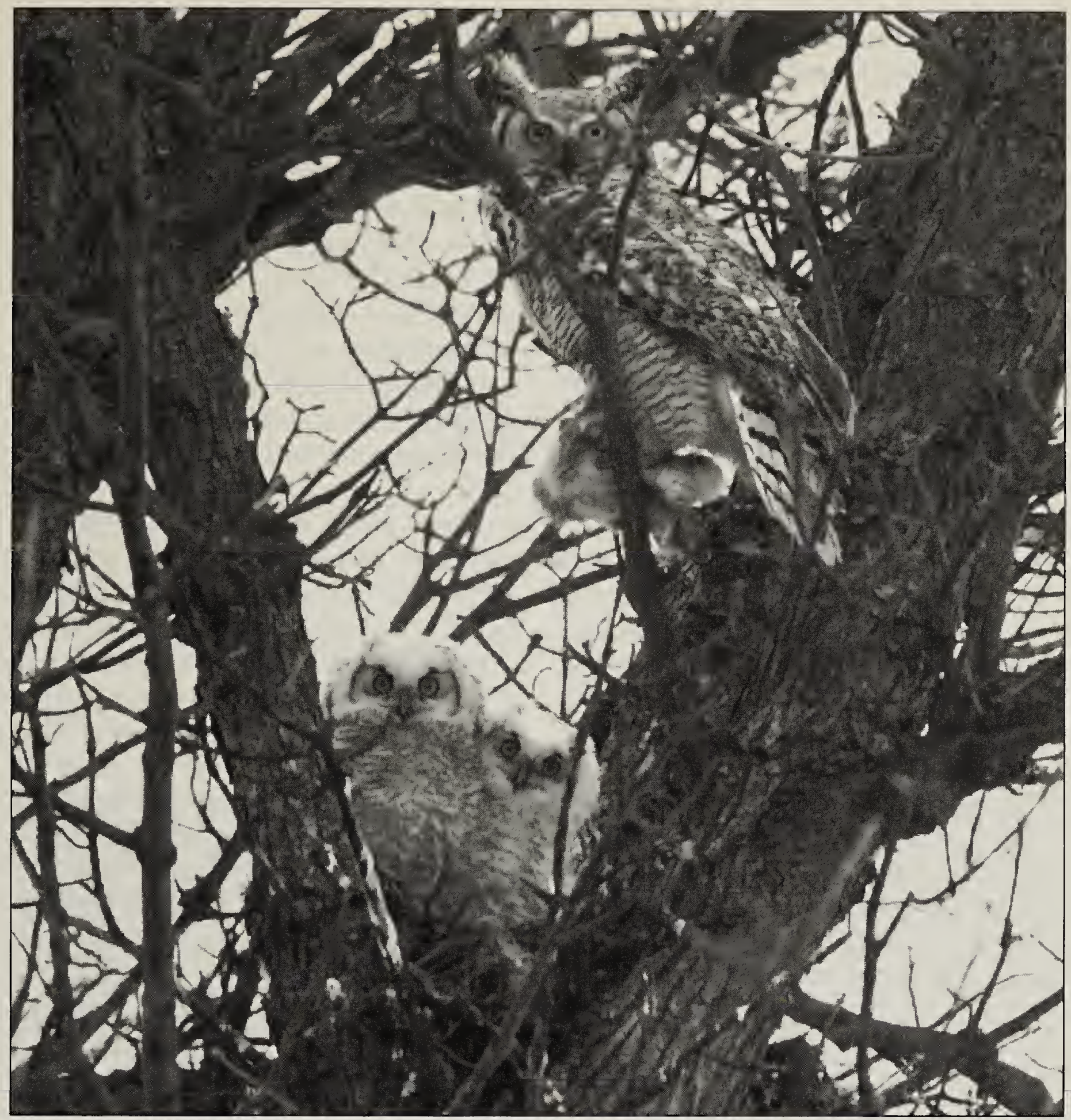

Figure 2. Adult bringing eastern cottontail to young in the nest at Wildwood Golf Course on March 24, 2006.

in a conifer. Two chicks fledged in the second week of April. I estimate clutch initiation for this pair to be January 23, which is consistent with the observations of local residents.

A third seemingly early nest was located in the Bois des Esprits, a patch of riparian forest on the Seine River near a new suburban housing development. The female was observed sitting on the nest from February 21 to March 21, with the male in attendance nearby; however, the owls were not seen near the nest in early April and no further information could be gleaned. Other Great Horned Owl nests in rural areas outside Winnipeg exhibited more typical phenology, producing fledged young in late May or early June, indicating laying in early or mid-March. None of 24 nests located in prairie and aspen parkland habitat in southwestern Manitoba during late April and early May of 2006 appeared early (K. De Smet, pers comm.). The locations and dates of nests in and near Winnipeg are summarized in Table 1. Locations are illustrated in Figure 1. All these nests produced two young, 
except the Bois des Esprits nest for which the reproductive output is not known.

January 2006 was the warmest January ever recorded in Winnipeg (recording began in 1873) and in 14 other locations in Manitoba (D. Marciski, pers. comm.). The average temperature in Winnipeg in January 2006 was $-7.4^{\circ} \mathrm{C}$, which is more than $10^{\circ} \mathrm{C}$ warmer than the long-term average of $-17.8^{\circ} \mathrm{C}$, and more than $3^{\circ} \mathrm{C}$ warmer than the highest previously recorded January average of $-10.6^{\circ} \mathrm{C}$ set in $1944 .^{3}$ In 2006 , temperatures were consistently well above normal throughout January, with only one day between December 21 and January 31 below normal. Minimum temperatures were especially high throughout the month, falling below $-20^{\circ} \mathrm{C}$ on only three days of the month, and falling below the longterm average minimum temperature of $-22.8^{\circ} \mathrm{C}$ on only one day of the month (January 22 , minimum of $-32.9^{\circ} \mathrm{C}$ ). ${ }^{3}$ The maximum temperature was above $-5^{\circ} \mathrm{C}$ on 24 days of the month. ${ }^{3}$

Exceptionally warm January temperatures were likely influential in the case of these early nests. Although the small sample size and the absence of highly localized weather data preclude statistical analysis, comparisons of fledging dates and average temperatures in suburban and rural areas point to the urban heat island (in combination with the unusually warm January) as an important factor in producing the differences noted in clutch initiation. To further investigate this possibility, I used the data from the 273 nest cards from Manitoba for Great Horned Owl in the Prairie Nest Record File to calculate clutch initiation dates. Egg dates were taken to indicate clutch initiation, (even though the eggs may have been laid previously), unless fledging dates provided a more accurate estimate. Records of "wellincubated" eggs, sitting owls without other data; and larger downy young were not included in any calculations, as estimating the onset of laying would have been too difficult. The dates I calculated therefore represent the latest possible clutch initiation, a conservative estimate rather than a precise measurement. Details of the nests with the 10 earliest clutch initiation dates are provided in Table 2.

There are 95 nest cards from Manitoba for which an estimate of clutch initiation is possible. Based on these, the average latest clutch initiation date is April $1 \pm 2.2$ days (standard error of the mean). The average of the nine records from Winnipeg is March $19 \pm 9.4$ days. The actual average clutch initiation dates are likely to be earlier for the reasons discussed above. There are six records of clutch initiation in February in the nest record file (not including the 2006 nests described above), the earliest being February 18. The fact that four of these six $(67 \%)$ records are from Winnipeg, when only nine of the $95(9 \%)$ nest records are from that city, further suggests the importance of the urban heat island effect. Of the six February clutch initiation records, four were in years with above average February temperatures and data for one year are lacking. The two earliest records were in years that were approximately $7^{\circ} \mathrm{C}$ above average. This also suggests temperature acts as a trigger for egglaying.

I also compared data on winter snowfall and snow thickness from Environment Canada weather stations for the three early nests in 2006 and the 10 earliest records from the Prairie Nest Record File, summarized in Table 3. 
Nine of the 10 nests for which there were data on total winter snowfall were at locations, and in years, with 3.6 $40.8 \mathrm{~cm}$ less than average snowfall. The only early nest with above average snowfall was in Assiniboine Park, Winnipeg in 1987 (3 cm above average). The amount of snow that remains on the ground probably has more biological significance to the owls and their prey than snowfall per se and, for five of the six nests where data were available, the snow on the ground on the last day of February was $11-25 \mathrm{~cm}$ less than average. The 1987 Winnipeg nest again provides the only exception. Unfortunately, more useful data, such as average snow thickness prior to clutch initiation, were not obtainable. These data suggest that snow thickness, which may be correlated with temperature, may also be a factor in determining nesting phenology. Prey availability, another potentially influential factor, could not be evaluated.

The phenomenon of early nesting by Great Horned Owls in response to warm winter temperatures has been reported from elsewhere in North America, e.g. New York and Wyoming. ${ }^{2,9}$ Great Horned Owls initiated a clutch on approximately December 22, 2001 at an international airport in Montana. ${ }^{6}$ Above average November and December temperatures and artificial lighting at the airport may have been factors in this early nesting. ${ }^{6}$ None of the early nests in Winnipeg, 2006 were in well-lit areas, though there were a few street lamps nearby in each case.

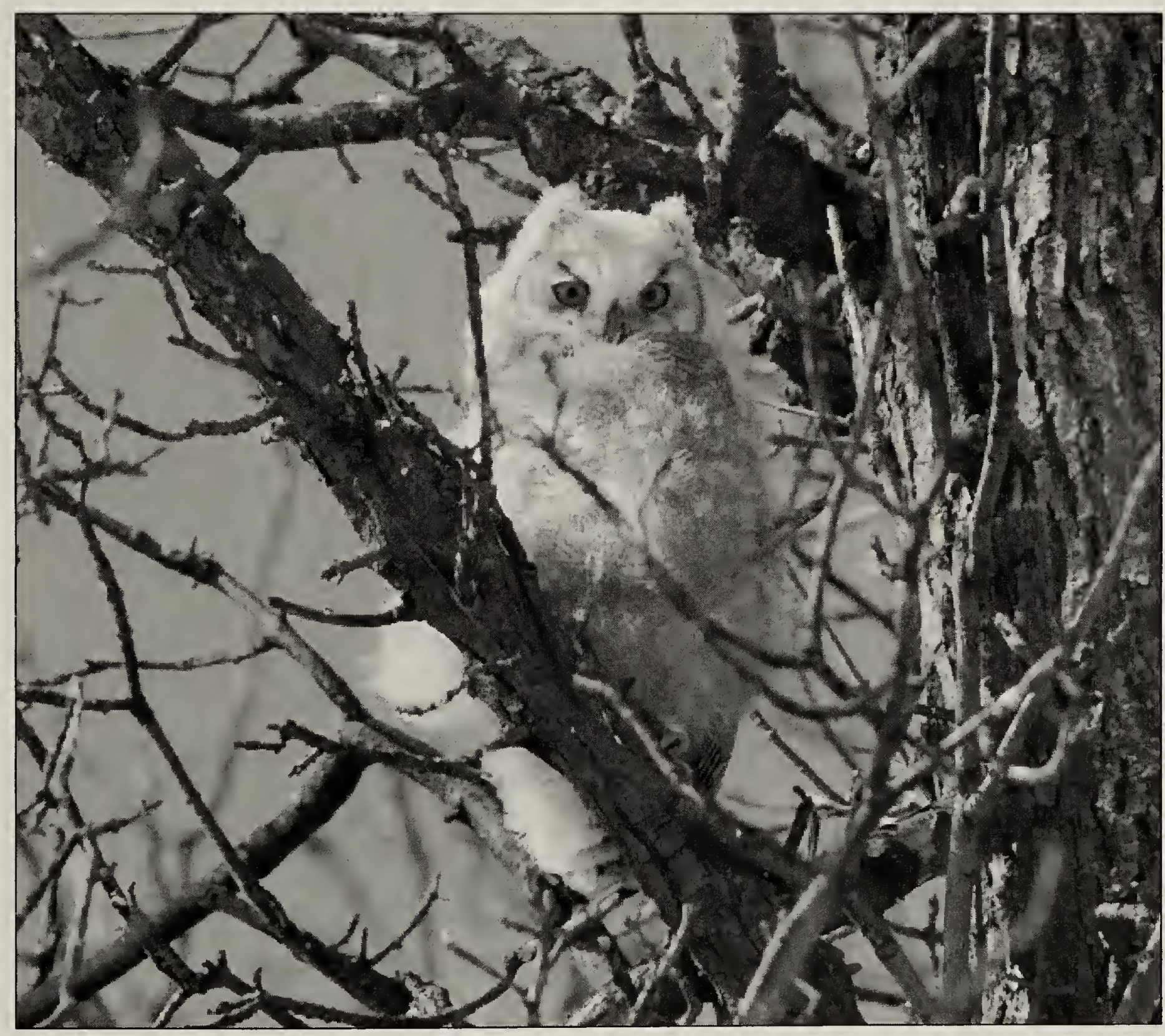

Figure 3. "Branching" young at Wildwood Golf Course on March 31, 2006. 


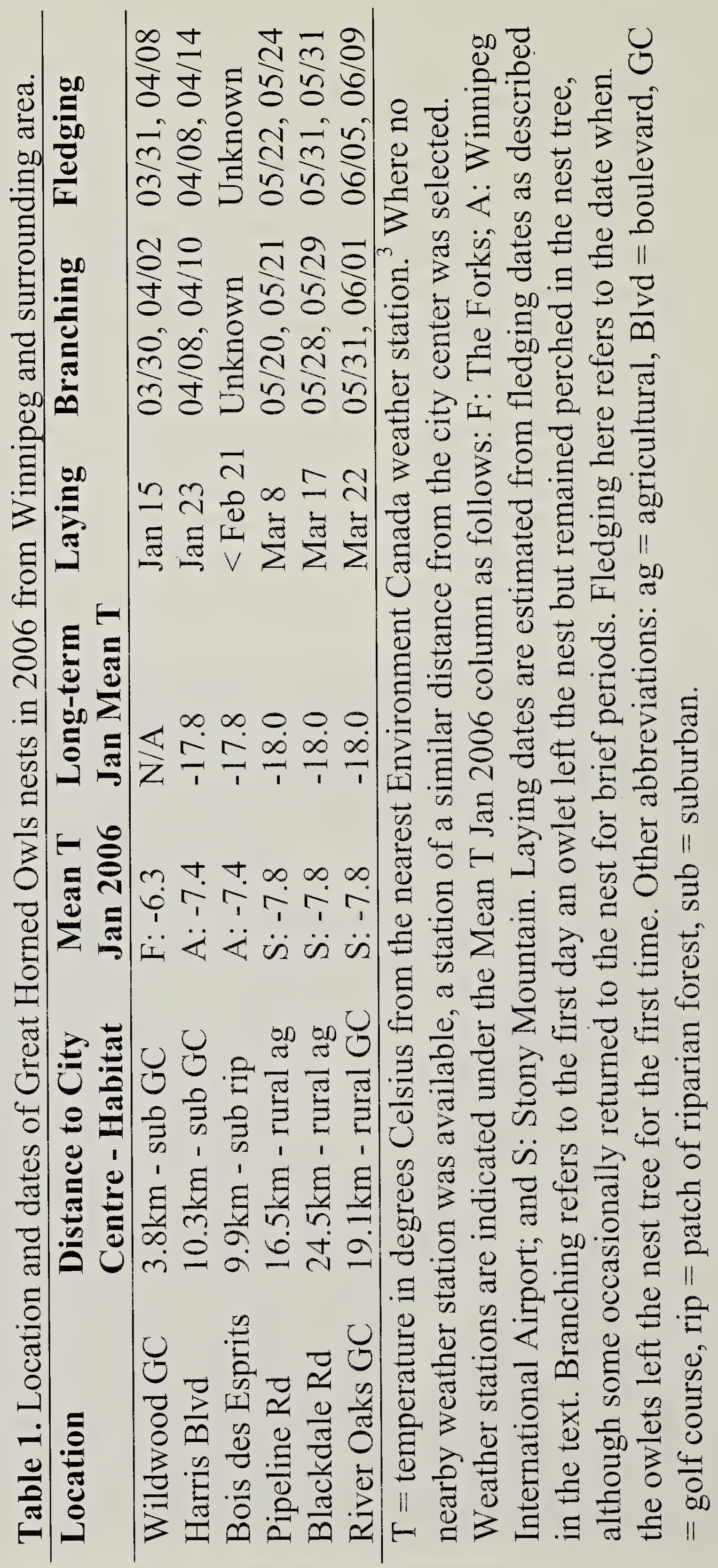




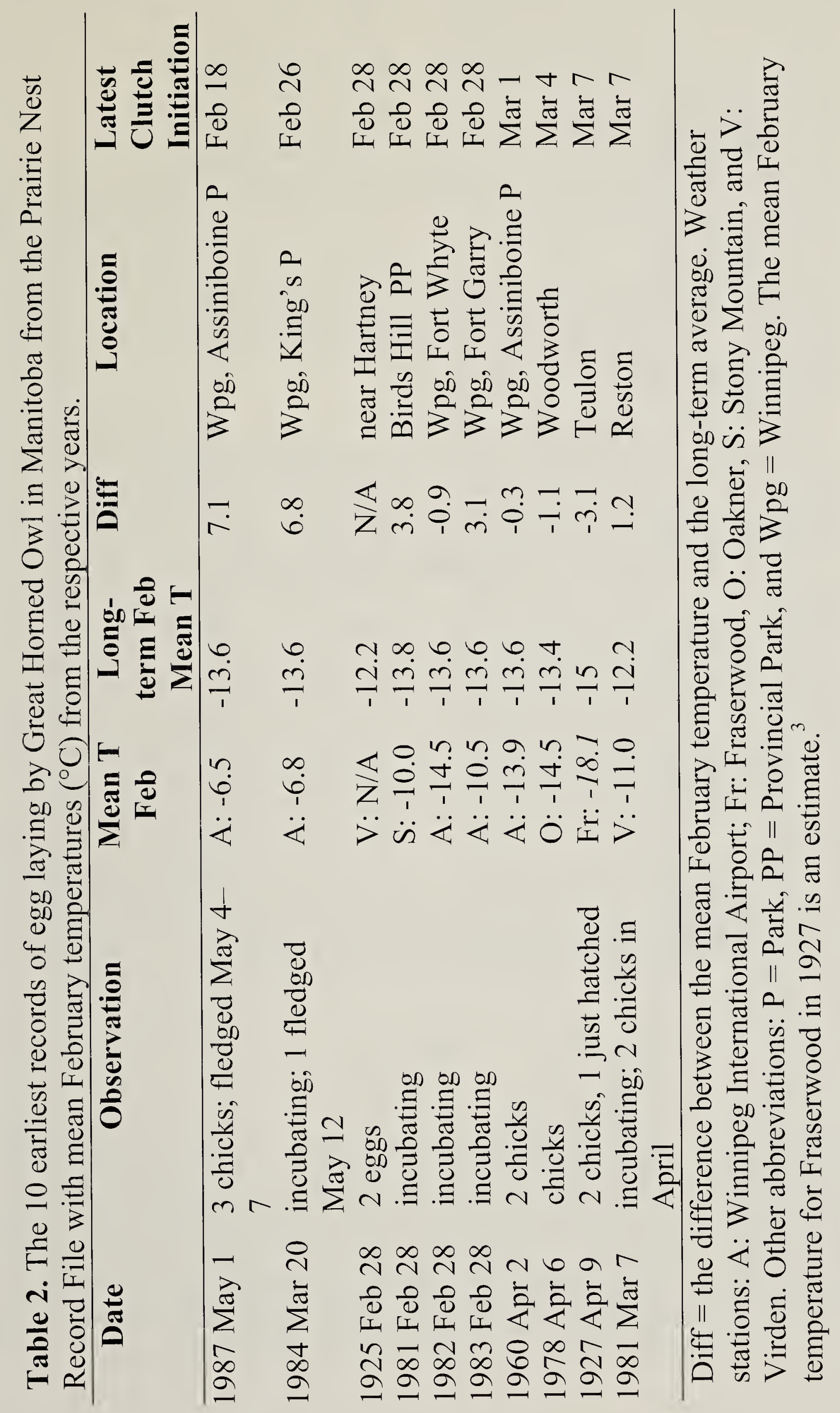




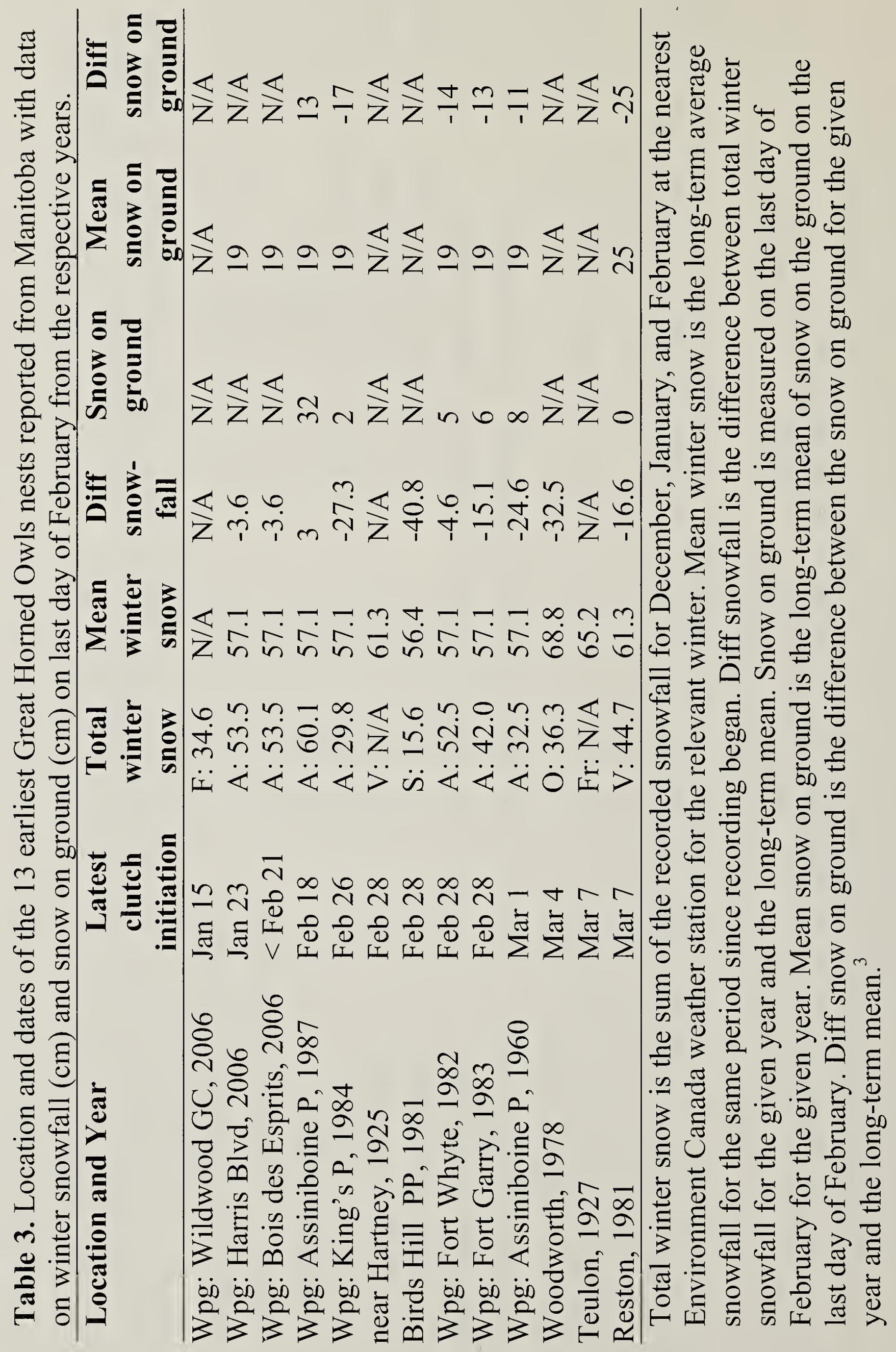


The exceptionally early nests documented here provide anecdotal evidence for two hypotheses: 1) that temperature is one of the cues used by Great Horned Owls in timing their breeding effort, possibly overriding photoperiod under certain conditions, and 2) that Great Horned Owls and other owls in suburban environments may benefit from the urban heat island in terms of early nesting. There is some evidence for the former from the Barn Owl,$^{1,8}$ and for the latter from the Eastern Screech-Owl. ${ }^{4}$

\section{Acknowledgements}

I would like to thank all those who reported observations of Great Horned Owls including Alfred Aug, Greg Buzza, Kevin and Alison Campbell, John Hays, Randy Mooi, Nick Devine, Robert Robinson, and Dennis Swayze. I am grateful to Dale Marciski, the Outreach Officer at the Meteorological Service of Environment Canada, for his assistance in gathering climate data. I also thank Ken De Smet, James R. Duncan, Stuart Houston, Karla Kinstler, Janis Klapecki, Nicola Koper, Rudolf Koes, Randy Mooi, Spencer G. Sealy, Peter Taylor and an anonymous reviewer for their thoughtful comments which improved an earlier draft of this manuscript.
1. ANDRUSIAK, L. A. and K. M. CHENG. 1997 Breeding biology of the Barn Owl (Tyto alba) in the lower mainland of British Columbia. In: Duncan, J. R., D. H. Johnson, and T. H. Nicholls (eds.). Biology and Conservation of Owls in the Northern Hemisphere. Second International Symposium: General Technical Report NC-190. USDA Forest Service, St. Paul, Minnesota. p. 3846.

2. ELDER, W. II. 1935. Early nesting of the Great Horned Owl. Auk 52: 309-310.

3. Environment Canada. Weather Pages. http:// weatheroffice.ec.gc.ca

4. GEHLBACH F. R. 1994. The Eastern Screech Owl: Life history, ecology, and behavior in the suburbs and countryside. Texas A\&M University Press, College Station, U.S.A.

5. HOLLAND, G. E, C. E. CURTIS, and P TAYLOR. 2003. Great Horned Owl. In: Manitoba Avian Research Committee. The Birds of Manitoba. Manitoba Naturalists Society, Winnipeg, MB. p. 227

6. HOLT, D. W., and S. DRASEN. 2001. Early nesting by Great Horned Owls in Montana. Journal of Raptor Research 35: 66-67.

7. HOUSTON, C. S., D. G. SMITH, and C ROHNER. 1998. Great Horned Owl (Bubo virginianus). In: The Birds of North America, No. 372 (A. Poole and F. Gill, Eds.). The Birds of North America, Inc., Philadelphia, PA.

8. MARTI, C. D. 1994. Barn Owl reproduction: Patterns and variation near the limit of the species distribution. Condor 96: 468-484.

9. WATSON, G. H. 1933. Early nesting of the Great Horned Owl. Auk 50: 220-221.

"When the ground is completely bare of snow and a few warm days have dried its surface- It is pleasant to compare the faint tender signs of the infant year just peeping forth with the stately beauty of the withered vegetation which has withstood the winter- the various thistles which have not yet sown their seeds-. The graceful reeds and rushes, whose winter is more gay and stately than their summer-as if not till then was their beauty ripe." Henry D. Thoreau, Journal, Volume 1: 1837-1844.p. 471. 